\title{
NO PASSPORT REQUIRED: SOCIAL LEARNING INNOVATION THROUGH COLLABORATIVE ONLINE EDUCATION
}

\section{NO SE NECESITA PASAPORTE: APRENDER CON INNOVACIÓN SOCIAL POR MEDIO DE LA COLABORACIÓN ONLINE}

\author{
Gloria Aznar \\ CEU San Pablo University \\ mariagloria.aznarfernandezmonte@ceu.es
}

\author{
Elizabeth Frank \\ CEU San Pablo University \\ elizabeth.frank@ceu.es
}

\section{ABSTRACT}

In midst the ongoing COVID19 pandemic, there is an inherent need to consider the effects on education in poorer regions of the globe. Students from Western countries and more privileged backgrounds have managed to continue learning albeit Universities having closed in the most difficult moments of the Pandemic. Students from disadvantaged regions and poorer backgrounds however, very often remained isolated when their institution shut down during the pandemic.

In this paper the authors discuss a socially innovative initiative that enables building a community of international learning based on a popular methodology named COIL (Collaborative Online International Learning). The methodology relies on the use of openly available online platforms that allow students and lecturers to be connected digitally, thus making learning resources available to students no matter their location. It allows for an intense peer-to-peer learning environment and promotes the virtual teamwork on real cases and assignments.

\section{KEYWORDS}

COIL (Collaborative Online International Learning); E-learning; International Cooperation for Development Education; SDG.

CÓDIGOS JEL: 129.

Fecha de recepción: 29/03/2021

\section{RESUMEN}

En medio de la actual pandemia de $\mathrm{CO}$ VID19, hay una necesidad inherente de considerar los efectos en la educación en las regiones más pobres del mundo. Los estudiantes de los países occidentales y de entornos más privilegiados han conseguido seguir aprendiendo, aunque las Universidades hayan cerrado debido a la pandemia. Sin embargo, los estudiantes de regiones desfavorecidas se quedaron, a menudo, aislados cuando su institución cerró durante la pandemia.

En este artículo, las autoras discuten una iniciativa socialmente innovadora que permite construir una comunidad de aprendizaje internacional basada en una metodología popular llamada COIL (Collaborative Online International Learning). Basada en el uso de plataformas online de libre acceso que permiten conectar digitalmente a estudiantes y profesores, poniendo así los recursos de aprendizaje a disposición de los estudiantes sin importar su ubicación. Permite un entorno de aprendizaje entre pares y promueve el trabajo en equipo virtual sobre casos y tareas reales.

\section{PALABRAS CLAVE}

COIL (Collaborative Online International Learning); E-learning; Cooperación Internacional para el Desarrollo de la Educación; ODS. 



\section{INTRODUCTION}

The global range of the COVID-19 pandemic has led to unparalleled interruptions in education around the globe. Many professors, researchers, policymakers and other stakeholders such as the general public have expressed an increasing interest in determining how education systems in general respond to these new challenges and how as a result, students' educational experiences are changing worldwide.

In this article, the authors would like to shed more light on the educational challenges, ramifications and repercussions of the pandemic for students, lecturers and Higher Education Institutions. We will be taking a closer look at the education scenario of poorer regions of the globe, taking into account objective four from the Sustainable Development Goals (SDG 4) that aims to "ensure inclusive and equitable quality education and promote lifelong learning opportunities for all". This goal aims to provide equal access to affordable vocational education, eliminating gender inequalities and wealth disparities. The objective being to achieve widespread access to quality higher education.

In this situation, the University plays a key role in the implementation of the Agenda, not only as a key institution working towards the achievement of SDG 4, but also as an instrument in the formation of responsible and committed citizens. Through learning and teaching, students get equipped with the knowledge, skills and motivation to understand challenges and implement solutions. Fostering the capacity development of students and professionals in all countries and endowing and mobilizing youth also leads to social leadership. Overall, a reinforcement of the university's public engagement and involvement can be observed. Thus enhancing cooperation and cohesion for providing quality education involving cross country collaboration (SDG 4 and SDG 17). This will help form future socially responsible leaders that will be involved in the social challenges of society. Companies of the 21 st century need business leaders that are more aware of their responsibility towards society, more knowledgeable about the impact of their companies. Leaders who join forces to face the global challenges of the fight against poverty (SDG 1).

In this article, the authors would like to present some specific projects and methodologies that have the capacity to empower students and lecturers 
no matter where they are located. These presented tools are replicable and scalable and can also cater for the needs of internationalization of the Higher Education Eco-system. Since there are still many aspects that need to be faced, there will be a formal discussion about some of the main challenges that may be encountered along this journey.

The paper is structured in seven sections. Starting with an outline describing the current situation of the educational sector after the COVID 19 pandemic, the authors continue by presenting the methodology of COIL projects (Collaborative Online International Learning) and explain in depth how the COIL activity at the heart of this article was conceived. The theoretical background is provided whilst the objectives are described, before continuing to explain in detail how the implementation of this particular COIL project took place. The authors then take a critical look at the results before raising some interesting questions for further discussion.

\section{CURRENT SITUATION}

As times change, the necessity of adjusting learning styles and teaching methods increases. As Burner (2018) points out, there are several reasons why we need to conduct a change in education. He mentions, amongst other aspects, the increasing level of globalisation and technological innovations. In a globalized world, we are more and more connected and interdependent from each other. There is also a proliferation in society of combining two elements, the new and the social, as Herrero de Egaña (Herrero de Egaña, 2018) describes with the definition of social innovation as "new or novel ways for society to address relevant social challenges (RSRs) that are more effective, efficient and sustainable". Herrero de Egaña describes the social innovation not as a sum of innovation and social innovation, but rather merging both concepts operating as one.

In recent months, the COVID 19 pandemic has aggravated the overall educational situation and the need for change. It has exposed emerging weaknesses in the traditional education systems around the globe. It has become more and more evident that the world needs to rely on a more adaptable, flexible and more robust education system, especially as we are facing an increasingly unpredictable future (Wahab, 2020).

A growing number of universities have been obliged to find alternatives to traditional teaching, many turning towards online or digital learning, especially during lockdown scenarios that left University campuses closed for weeks and months. By March 2020, schools in more than 180 countries worldwide had to close which affected a humbling $87.4 \%$ of students worldwide, overall more than 1.5 billion, see Figure.1 (Raluca et al., 2020).

The pandemic and lockdowns have affected many regions in the world. One of the main challenges has subsequently been, to provide students access 
Figure 1. Percentage of Students affected by COVID-19 school closures, global

\section{Figure 1: Percentage of students affected by CoviD-19 school closures, global}

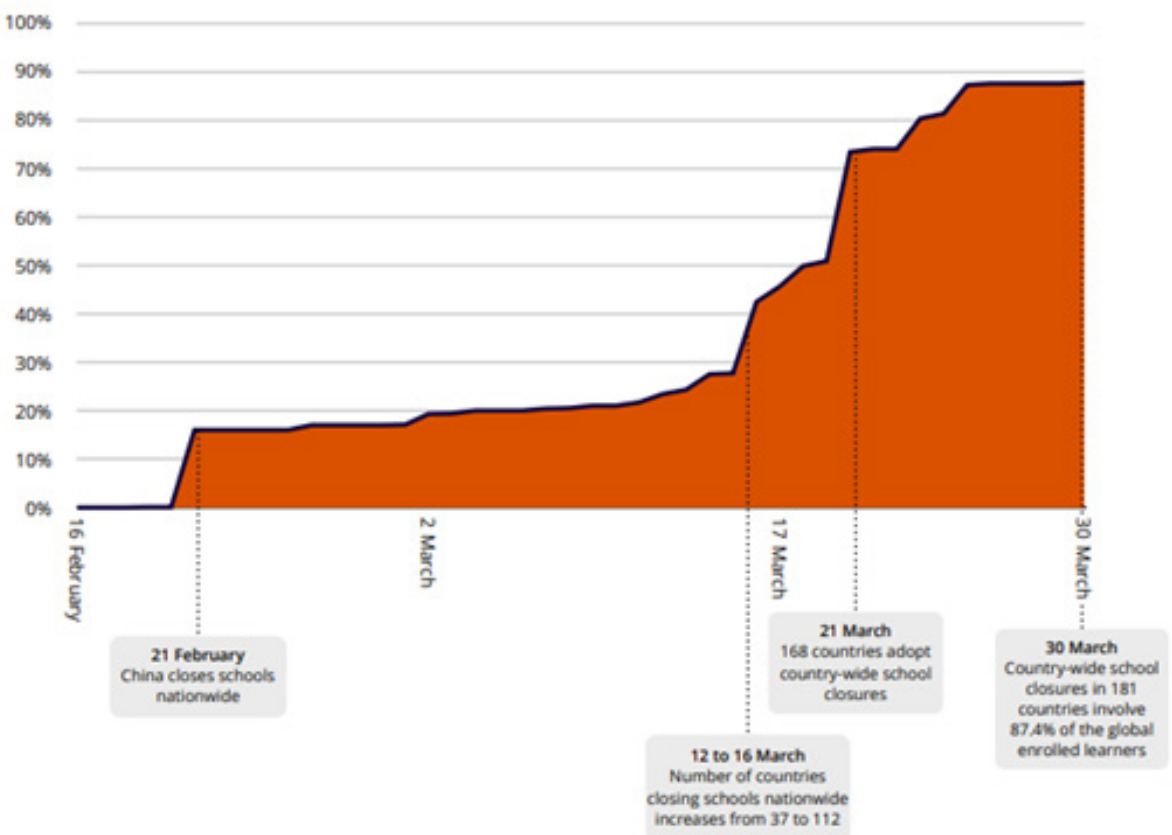

Source: Policy Brief - Education during the COVID-19 crisis (April 2020)

to education that permits a seamless continuation of their higher education. In many regions, efforts were made to support students to continue their education, by use of technology switching to online learning where possible. In some areas of the globe, especially poorer regions, educational television and the use of radio broadcasts and SMS were introduced to effectively communicate with the vast student population. This was and still is especially relevant in areas where internet is not available, connectivity not reliable or were the student community lacks devices to connect online. Providing accessibility to students is key to providing quality education.

On a positive note, Willms \& Corbett (2003) discuss the high level of technology acceptance of students also when technology is integrated into the education system. They furthermore state that a majority of students have mobile phones as they use them for texting, using social media or applications, which leads to the assumption that students are receptive to using technology also in a learning environment.

We have not yet returned to normality with many Universities continuing to provide classes online only, others adopting a hybrid teaching model, 
based on a student rotation system that allows for a reduced number of students being present in the physical classroom. It is unclear when Universities will return to pre-Covid like class settings, if at all. It may well be that the changes that we have been experiencing are here to stay.

Yet, there are more challenges ahead. Whilst policymakers are taking action to support students in their efforts to continue their education remotely and online, other challenges are just around the corner, such as a global pandemic-induced economic recession, political instabilities, further healthcare emergencies and overall educational challenges.

For the past years, the authors have been following the business proposal of UNIMAK University in Sierra Leone and have observed the inclination towards entrepreneurship. They agree with Lakovleka that individuals with entrepreneurial ambitions within developing countries show a higher engagement compared to individuals in developed countries (Lakovleka, 2011). They manage to seize opportunities by planning their own business and showing entrepreneurial spirit.

\section{METHODOLOGY AND THE CONCEPTION OF THE COIL ACTIVITY}

For the past twelve years, motivated students, lecturers and employees of the University CEU San Pablo alongside inspiring and inspired professionals from different private sector companies have been working alongside each other in various projects in the West-African country Sierra Leone. These projects are aimed at combatting poverty and empowering Sierra Leoneans from diverse backgrounds through educational programs and civic engagement. Social innovation projects address many challenges, the economic discipline being one of them (Pol, 2009).

Currently, the University CEU San Pablo team is formed by representatives of different disciplines, such as the Faculty of Medicine, the Pharmaceutical Faculty, Physiotherapy, the School of Media and Communication, the School of Business and Economics as well as the Faculty of Architecture. The Faculty of Architecture was the pioneering Faculty that initiated the Cooperation between Spain and Sierra Leone, in particular with UNIMAK University in Makeni. The School of Business and Economics joined the cooperation project in 2016 ensuring that the project was truly aimed at continuous international development cooperation not merely as one-off volunteering work.

Traditionally the University CEU San Pablo would organize two trips to Sierra Leone each year, to ensure continuity of the different projects in the diverse areas. Due to the severe situation caused by the COVID 19 pandemic, a physical trip was out of the question in 2020, and the idea evolved to substitute the yearly journey by a digital journey, thus connecting students, lecturers and professionals from the different countries and locations. The 
option of introducing a set of online workshops to mitigate the dramatic situation was supported by both Institutions. This would guarantee the continuous relationship between both Universities, UNIMAK and University CEU San Pablo, establishing a solid cooperation and collaboration. This is to institutionalize and integrate stakeholders (students, professors, business individuals, and other personnel) and community members. The focus is not only on education, creating and transferring knowledge but also on integrating the development of the country and the society. Hence, it is a win win situation.

The organization of an online collaboration and knowledge exchange was endorsed, giving participants the opportunity to develop a series of competences, skills and academic knowledge through a COIL (Collaborative Online International Learning) project, which will be ongoing in time. An interdisciplinary and intercultural week course was designed allowing for an exchange of knowledge and experience. The audience being students, professionals and professors who collaborate on solutions to specific challenges that are posed.

University CEU San Pablo students that are currently studying a Bachelor's degree in Business Administration and Management, a Bachelor in Marketing or a Bachelor in Economics together with students from UNIMAK University from different disciplines such as the Master of Finance, Business and Administration, Economics bachelor, and students from the Agricultural Faculty, were invited to take part in an intensive online event between both institutions.

The organizers of the joint event decided to implement the methodology of COIL, Collaborative Online International Learning. The COIL Handbook as published by the University of Minnesota (2016) defines this approach as "...a model for teaching and learning that promotes the development of intercultural competence (the ability to communicate effectively and appropriately with people from other cultures) through a shared online multicultural learning environment.".

In the Faculty Guide for Collaborative Online International Learning as published by the leading SUNY COIL Centre in New York, a similar definition can be found: "COIL, also referred to as globally networked learning and virtual exchange, is a new teaching and learning paradigm that promotes the development of intercultural competence across shared multicultural learning environments. Through the use of internet-based tools and innovative online pedagogies, COIL fosters meaningful exchanges between university-level teachers and students with peers in geographically distant locations and from different linguacultural backgrounds."

As both definitions indicate, a COIL activity focusses on the intercultural aspect of participating students, by providing activities and assignments 
that are developed in cooperation with students at different locations and varying backgrounds, relying on technology and digital classroom settings. As Hans de Wit describes it in his article COIL - Virtual mobility without commercialisation (2013): "The term 'collaborative online international learning' combines the four essential dimensions of real virtual mobility:

1) It is a collaborative exercise of teachers and students;

2)It makes use of online technology and interaction;

3) It has potential international dimensions; and

4) It is integrated into the learning process."

COIL allows collaboration between students and teachers from different universities without the need to travel abroad. In times of a global pandemic, this is the beauty of COIL. It can easily be implemented since it guarantees social distancing and sanitary safety, and yet it provides students the pleasure of working with peers in different countries around the globe. The collaboration takes place in an online environment and it is carried out through planned activities usually integrated into the program of a specific subject. It merely requires the collaboration of lecturers of both institutions, whose task it is to define the activities to be developed by the participants in mixed international groups during the actual COIL module. Lecturers then ensure the correct implementation and evaluation of the activity.

In the following diagram (Figure 2) you can see in more detail what a COIL consists of and the competences that students and also involved lecturers can develop.

Figure 2. COILs What, Why and What For

\section{COILS WHAT | WHY | WHAT FOR \\ COLLABORATIVE ONLINE INTERNATIONAL LEARNING}

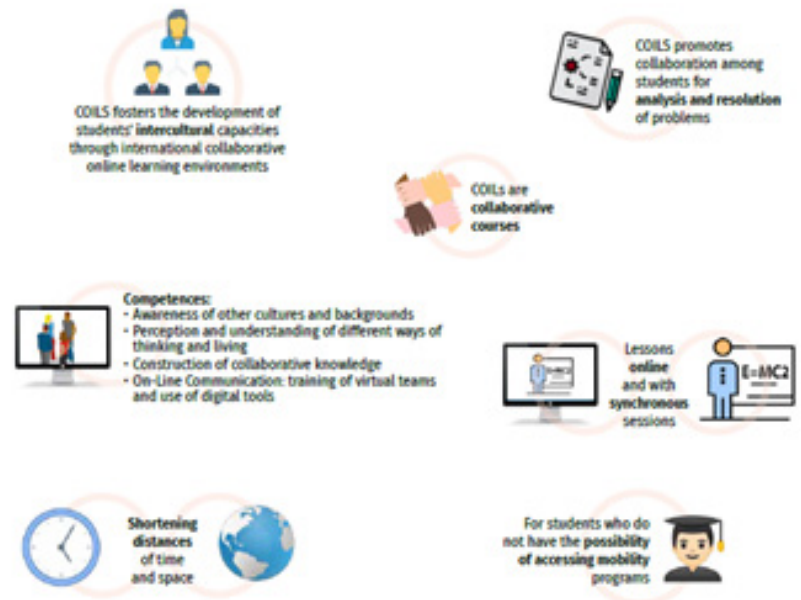

Source: CEU ViceChancellor International Reations CEU,2020 
The benefits of COIL are derived from the direct interaction between participating students that have different perspectives. In many instances these differences are culturally motivated. It is therefore a good idea to focus on team projects and active learning, providing students a discussion platform where they can exchange their views, ideas and where they can work jointly on an assignment.

The design of COIL projects works best when lecturers share the responsibility for the developed activities and content. Co-developing courses and modules however is not always possible. The design of the CEU-UNIMAK COIL was based on the specific methodology used for the development of an online course. It was built upon the following six stages (Marciniak, 2017):

1- Analysis of the educational problem, which was the inability to travel to Sierra Leone amidst an ongoing pandemic while intending to ensure continuity in the international development cooperation and providing the students with the opportunity of an international experience.

2- Justification and objectives of the project, which clearly involved the idea of providing students with the possibility of gaining international experiences, touch-basing with peers from abroad, but from home. In addition, the aim was to improve students' competences, such as remote teamwork, improved communication, planning and organization skills in an international and online environment as well as intercultural competences.

3- Proposed project perspectives, with the ideal scenario being a successful implementation of this COIL activity, effectively achieving objectives as outlined above and further below. The alternative being the non-implementation of the project, thus depriving students of the possibility of acquiring the knowledge, competences and contacts provided by the project, and off course the international experience.

4- Pedagogical planning that allows introducing an activity, independent of the curriculum and related to international development cooperation, which is so cutting-edge and relevant that it has not yet been integrated into any formal syllabi at either Institutions involved in the project.

The COIL activity was designed by University CEU San Pablo and shared with UNIMAK's Dean and professors to assure the alignment. The time horizon of each task was defined, the mode of collaboration between international, mixed teams and the required learning outcomes and deliverables were agreed upon as will be discussed in more detail furtheron.

5- Design of the pedagogical proposal which is based on a twofold approach. On the one hand, there are master classes which are 
designed in a way that students obtain the theoretical knowledge needed to perform a given assignment or challenge. On the other hand, students work in international, mixed groups that allow for a more engaged and applied learning experience. According to research carried out by Hoag and Swan (2000) amongst others, collaborative learning is most successful when projects are executed by small groups. Following this insight, the creation of groups was set at a maximum of five people per group.

6- Planning of operational aspects, which resulted in the use of the platform MS TEAMS, which was hosted and organized by the University CEU San Pablo. Technology, in this case, becomes an ally (Martinez, 2014) allowing contact and participation using also social platforms as WhatsApp, Skype.

The material that was used in Master classes was furthermore made available by email to the participants, mainly due to the technical limitations on the side of UNIMAK, which will be explained in more detail further down.

7- Evaluation system including the academic grading of the activity and how students evaluated the project. Bringing the students from different continents and different backgrounds together. Although the project was not graded, students were still enthusiastic about the possibility of working together as can be reviewed in the RESULTS section of this paper. Students were eager and motivation was high. The goal was to stimulate social innovation (Herrero de Egaña). This is the new paradigm, not only focusing on technology and industrial society and avoiding any social hype but creating cohesion that brings changes to the development of Sierra Leone. A youth willing to take ownership in development projects and inspiring other students from both cultures (Spanish and Sierra Leone's) to initiate changes, enhances cooperation and cohesion for gaining quality education (SDG 4 and SDG 17). The company of the 21 st century needs different business leaders, more aware of their responsibility to society, more knowledgeable about the impact of their companies. Leaders who join forces to face the global challenges of the fight against poverty (SDG 1)

After several months of planning, following the onset of the Covid19 pandemic, both Universities implemented the project together and the pilot was successfully launched on July 21 st, 2020, at the end of the academic year 2019-2020 (See appendix for details of the program).

\section{THEORETICAL BACKGROUND}

Cooperation for development and international experience are gaining more and more importance for students. Building intercultural 
competencies are important components in the internationalization strategy of Higher Education Institutions. Interculturality is summarized by Deardorff as the ability to communicate effectively and appropriately in intercultural situations on the basis of one's intercultural knowledge, skills and attitudes (Deardorff, 2006). According to Bennet, 1998, intercultural sensitivity is not something static, but can be progressively developed through training and education.

Inspired by the Theory of the psychology of Use and Gratification, it is assumed that people actively use those means that they find satisfactory. In order to achieve good learning results, we want to offer an activity that learners find attractive and engage in, in order to find rewarding elements. Katz, Blumler and Gurevitch emphasize an essential point: if the assignment is optional and not evaluated, then the mere fact of competing to offer the best work is a motivation in itself for participants. Even if it is not taken into account for a grade, the members themselves will qualitatively evaluate the work of their peers and their own (Sluijsmans, 2003).

The authors have chosen the COIL (Collaborative Online International Learning) project based on the learning needs of students and also to be able to create satisfaction for the students, besides being able to achieve gratification in the process, which refers to the satisfaction that the participants experience when joining in the process itself (Cutler and Danowski, 1980).

To complete the above, it is imperative that the professional possesses a deep understanding of diverse cultural contexts. Successful work in an increasingly globalized and virtual world requires specific skills to navigate cultural differences. This terrain can be treacherous, especially when people come from very different cultures and backgrounds and are expected to work together in harmony. Even with English as a common language, it is easy to fall into cultural traps that can jeopardize careers and risk business.

The Massachusetts Institute of Technology (MIT) recognizes the upsurge of globalization and in its program of Digital Transformation includes a complete course on Cultural Awareness when doing Business in Global Contexts. The program recognizes the importance to understand the culture's diversity (MIT,2020)

\section{OBJECTIVES}

One of the main objectives of this COIL-project is to promote the cooperation between University CEU San Pablo and UNIMAK University, helping the well-being of Sierra Leoneans and to make a positive social impact by designing solutions and providing recommendations to economic challenges. Recognizing the social challenges and applying social innovation. We refer to social innovation not only looking for brand new 
ideas but also old ideas applied differently (Philis, 2018). Social innovation provides novel and original ways of tackling 'problems'.

From an academic point of view, the overall objective of creating a global experience is at the center of this project. The goals can furthermore be classified into general objectives and specific objectives.

The general objective is to carry out an innovative project at international level in collaboration with an international partner to ensure global, relevant and multicultural training for students and teachers and continuing our relationship and development cooperation.

The specific objectives fall into several categories. First, there is the international experience for students, professors and professionals, without the need for geographical displacement. The COIL module as a teaching method facilitates interaction with students from other disciplines and nationalities, in mixed working groups, using English as a language and without the need to travel abroad, but taking advantage of the benefits of collaborating in a virtual, intercultural and stimulating environment.

Second, a number of professional competences are developed. This project enables students to improve a series of transversal skills and competences that are valuable for their subsequent professional development. It enriches the Curriculum Vitae and fosters knowledge of the business and cultural environment and the challenges that may arise in the future. Students work on a wide range of skills and competences such as the ability to organize and plan work, self-management, responsibility at work, the ability to work in a team, both nationally and internationally, autonomy and proactivity, the ability to solve problems and adapt to unforeseen changes and challenges, initiative and the management of interpersonal relationships, besides improving oral and written communication skills.

Third, COIL enables the personal development of learners. Involved students achieve meaningful and relevant social learning and social innovation with the aim of scaling impact. It aims to develop learners of integrity, with the capacity for understanding and critical analysis. The aim is to develop relevant solutions to challenges that simulate business reality. This type of activity encourages perseverance, decision making, negotiation skills and conflict resolution skills, cooperation in a virtual environment, inspiration of critical thinking and judgment, improvement of intercultural skills and knowledge of the other country as well as improving language skills. The continuous use of different communication channels allows the learner to better understand and use digital tools. All of these improve the graduate's profile and increase employment opportunities.

Fourth, a COIL can be introduced and consolidated as a learning strategy that favors the motivation and interest of learners to learn. It allows intrinsic and extrinsic motivation to be fostered through various factors that are 
included in the collaborative activity. Through challenges that need to be overcome, students' curiosity and creativity are awakened. This also allows for greater involvement, participation, motivation and commitment on the part of the students.

Fifth, the strength of the project lies in the diversity of the participants who are part of this initiative. The aim is to pool the knowledge and best practices of all participants and jointly explore the application of digital technology to enhance collaborative learning internationally. The full potential of innovative technologies to solve today's education challenges can be harnessed.

Sixth, by diversifying the modalities of cooperation, this allows an Institution to increase the degree of internationalization. It is no longer sufficient to exchange students at ERASMUS or bilateral level. Universities have to play a greater role, which translates into a diversification of international activities, intensification of inter-university collaboration that can lead to the joint development and design of activities, modules, subjects, courses and degrees, in order to meet today's demands and to be more competitive. Not only does it strengthen the cooperation between universities at an international level, for a Faculty this can provide a strategic advantage compared to other Higher Education Institutions.

Finally, a COIL awakens the desire for internationalization in students who have not shown interest in international mobility. And going further, it can positively stimulate the interest in international development activities and support for underprivileged regions, communities and individuals. It allows students to develop social and emotional competence, allowing them to become aware and understand the differences in education opportunities around the world. Building a community of committed individuals should also be part of the overall objective.

\section{IMPLEMENTATION}

The COIL activity in format of a digital journey to UNIMAK which was jointly organized and launched between CEU San Pablo and UNIMAK University, was a means to tackle the impossibility of organizing the yearly trip to the African country of Sierra Leone due to the ongoing COVID-19 pandemic. It is foreseeable that the project will continue to be proposed in the online version even after the end of the pandemic situation, regardless of the trip taking place or not, as more individuals can join.

A number of professors at each Institution was involved in the preparation of this online event, to ensure that the proposed activities were indeed aligned with the learning objectives at each Institution. Faculty of both institutions exchanged feedback and agreed on the concepts to be applied 
as well as the timelines, dates, participants, logistics and expected learning outcomes.

It was decided that the technology to be used was to be MS Teams, hosted and organized by University CEU San Pablo.

A document ("First Steps Guideline") was prepared with a general timeline including milestones of the different preparation activities, assigning tasks to each member of the organizing committee. Thus ensuring that no aspect of the COIL was overseen or forgotten. A general checklist was formulated including aspects such as:

- Commitment of the teachers involved

- Ensuring institutional support from both sides

- Contact of external professionals (who will be invited and who is in charge)

- Exchange of list of final participants from each country

- Create teams and exchange student contact details, including explicit permission to share contact details, such as emails and telephone numbers (in order to comply with privacy laws in both countries)

- Determine the agenda and make sure we reach agreement on the dates and timelines

- Define dates of presentations of the previously realized successful projects from previous years, including updates

- Fluid communication between Universities

- Discuss progress in class to optimize the experience

- Invite other professors to join the project.

Both institutions agreed on the date of July 21st, 2020 for the Kickoff of the Virtual Journey - COIL. The Agenda items for the following days included an Institutional Welcome from the highest University Authorities of both Institutions, followed by a general presentation of each of the Universities to all connected participants. In the second part of the program, the COIL project was presented, including the benefits for students and Institutions.

Following, the objectives of the Digital Journey were outlined and students had the opportunity to do an intercultural icebreaker activity. This intercultural icebreaker is a key component of every COIL. This activity enables participants to get to know each other and to comfortably interact with each other. There were three steps within the intercultural activity that was designed for this COIL. In step one, virtual Teams that had previously been created by the organizers were communicated to students via a presentation slide shared with all participants in the MS Teams Session. In Step two, the challenge that students would have to work on in their respective international teams was launched to the students. The task was for each group to develop a logo and/or a slogan for the UNIMAK - CEU cooperation, allowing students to contemplate together on how they view 
the ongoing cooperation. Students were then sent off into their respective breakout groups in the MS Teams environment where they engaged in creative discussions. In step 3, each team was to present its developed solution. This was the first interaction between students from Sierra Leone and Spain.

The following days' program included several interactive presentations that could be best described as Master classes, provided by some of the Spanish participants involved. There were sessions about SWOT-analysis (Strengths, Weaknesses, Opportunities and Threats) and PESTEL-analysis (Political, Economic, Social, Technological, Environmental and Legal aspects), both of which are methodologies that help analyze and understand a business' environment and comprehend trends. Both frameworks serve to develop business strategies.

A further session explained the CANVAS methodology (Osterwalder and Pigneur, 2010), which allows to describe the business model in a synthesized form by means of nine blocks on a single page, including information about customer segments, the business value proposition, the distribution channels, customer relations, the revenue source, key resources, key activities, key partnerships and the cost structure.

Another technique that was presented was the Elevator Pitch, this being a technique that describes a business idea, product, or company in such a way that any listener can understand it in a short period of time. The name is derived from the time it typically takes to ride in an elevator, which usually is just a 2-3 minutes time window. The delivered description would typically explain who the product is for and its features and benefits. It briefly explains the skills and objectives of the business. It works to attract attention and convey it in an understandable, exciting and passionate way.

Another stimulating presentation was about Design Thinking (Brown, 2008). This is a methodology that focuses on providing solutions to complex issues or potential problems.

Finally, a creative and entertaining session on Neuromarketing took place. The science of Neuromarketing studies the brain to gain insight and predict consumer behavior and consumer decision making. The COIL Session on this topic was designed in such a way that students had to proactively associate colors with brands and market segments.

After finalizing the Master-class presentations, students with entrepreneurial drive became the protagonists. Several students from UNIMAK presented their respective products or services that they had previously developed and in some cases they had already launched them to market. Also students that had no previous experience could present their ideas and concepts and request feedback. 
Students were supported along the way, but were encouraged to take initiative, following up with questions and sharing ideas. There was studentdriven competitiveness that motivated students to improve their results.

As supporting element, in each country, Spain and Sierra Leone, one student acted as a leader/coordinator to assure the continuity of the program. Delays occurred often as the culture in Sierra Leone's timing is different from Spain. In addition, connectivity issues played a big role, adding to frequent delays.

\section{RESULTS}

A survey was carried out using Microsoft Forms to measure the success of this activity. Some aspects on which information was requested included the topics of the Master Sessions, the overall program, the lcebreaker activity, the degree of usefulness, the level of engagement, the collaborative elements, the competencies acquired during the COIL and overall satisfaction. Students were asked to include reflections on the contributions of the COIL in order to measure and improve the event for future editions.

Interest in international mobility with a development country was generated among the students, although a few showed resistances to travel to Sierra Leone. The purpose of this collaboration is not necessarily travelling but working together throughout the year. Sadly, Sierra Leonean students have many difficulties travelling, as VISAs are difficult to obtain and a trip is very costly.

After venturing on this Virtual Journey, a large majority of the involved Spanish students showed interest in getting to know Sierra Leone better. They have expressed interest in opportunities to be more directly and actively involved in the development of the country.

\section{CHALLENGES AND FURTHER DISCUSSION}

There are technological requisites that have to be in place in order to successfully conduct a COIL. Guaranteeing connectivity is key to a seamless execution of the COIL. Therefore, it is important to assure a stable internet connection and that each participant has the device to connect, which can be a phone, tablet or computer.

In 2019 (figure 3) there were 6,73 million mobile phone subscribers (The Global Economy, 2020) in Sierra Leone.

Worldbank data extracted from Sierra Leone's country profile indicate that mobile cellular subscriptions (per 100 people) reached $88.5 \%$ in 2018 in the African country (Worldbank, 2018a). But only a 9\% of individuals of the total Sierra Leonean population use the Internet. A further important figure is the amount of Internet Providers in Sierra Leone. There are only 
Figure 3. Sierra Leone: Mobile phone subscribers, in millions, 1960 2019

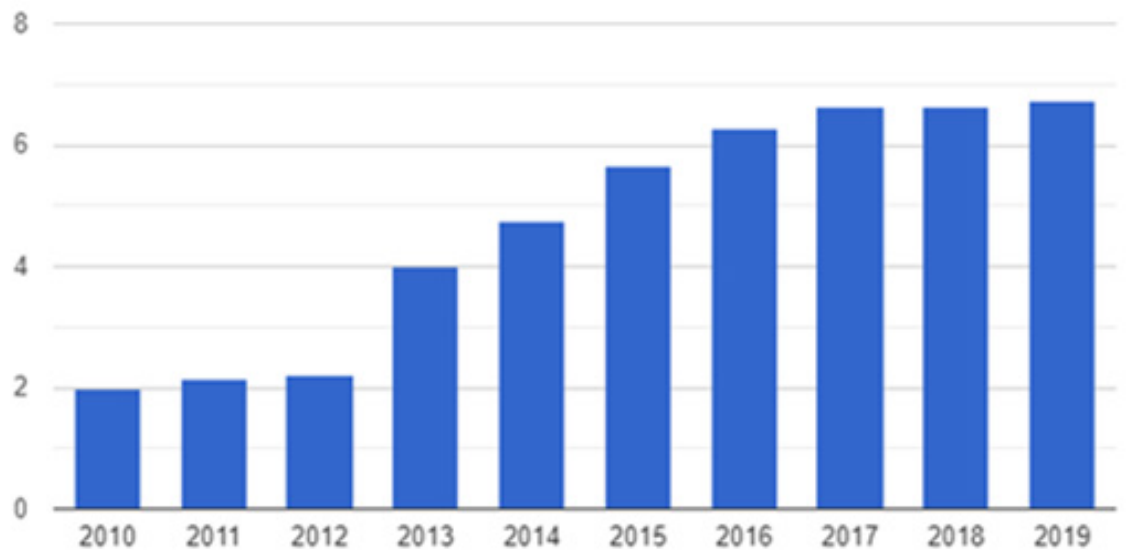

Source: The Global Economy (2020)

three Internet Providers and as a result the cost of Internet Service is high. Nonetheless, Universities and some cafes provide Wifi for free which would support the data above (low internet penetration). Young people would mostly use their mobile phones to access internet (Wittels, 2018).

When comparing with the Worldbank data extracted from Spain's country profile, we can observe that in 2018 there were $115 \%$ of mobile cellular subscriptions per 100 people in Spain, with $86.1 \%$ of individuals using the Internet (Worldbank, 2018b). Overall, we can witness an important digital divide between Spain and Sierra Leone.

In order to be able to execute the COIL activity, UNIMAK University provided the internet connection. Though some students had connection difficulties (internet downtimes), the resilience of students from both countries converted the problem into an opportunity. Students turned to social media to connect with each other, trying to overcome these difficulties

Since the timing of the Digital Journey coincided with the beginning of holidays, which students started straight after the completion of the COIL, the sample of responses is not representative. Next time the survey should be launched during the sessions to ensure sufficient quantitative and qualitative feedback.

The common language used was English. A summary of the participants can be viewed in table 1 . 
Table 1. Summary of participants

\begin{tabular}{l|c}
\multicolumn{1}{c|}{ PARTICIPANTS } & \\
\hline Students & 26 \\
\hline Professors & 4 \\
\hline University Staff & 6 \\
\hline Hours & 12 \\
\hline Days & 3
\end{tabular}

Source: Own elaboration

The main motivations for Spanish students was to be the principal actors in the first presentations, for Sierra Leonean students it was the digital presence of their own professors.

\section{CONCLUSION}

Taking into consideration the repercussions of the global COVID-19 pandemic on education worldwide, policymakers around the globe have put in place sensible and effective actions to avoid its further spread.

In order to continue and intensify international development cooperation between partner universities in the field of education, the Virtual Journey COIL was conceived with the idea of bringing students and continents together. Promoting collaborative learning amongst culturally diverse peers, strengthening civic engagement of the student population, practicing social inclusion and deepening solidarity are at the heart of this educational project. Furthermore, Higher Education Institutions are still adjusting to changes in the educational environment by trying to incorporate IT skills and online learning to the classrooms in order to reduce the skills gap of students and graduates (Frank and Aznar, 2020).

The presented activity increases the degree of internationalization of the Faculties involved. It is a tool for quality improvement and increases the competitiveness of the university, both nationally and internationally. It favors the professional career of students, professors and researchers, it increases the quality of teaching and research, and at the same time increases the possibility of attracting new students. It also increases the reputation and international visibility of the Institutions.

And finally, the Virtual Journey-COIL presented in this article is clearly aligned with two of the United Nations Sustainable Development Goals (SDGs):

This project has expanded and improved the traditional configuration of education, introducing a variety of international, intercultural and digital elements. The authors believe that every small action like this adds up 
towards achieving the overall objective of United Nations Sustainable Development Goal 4 (Quality Education).

In addition, goal 17 of the SDGs which is called "Partnerships for the Goals that recognizes, enables and encourages different stakeholders to head out and actively engage in making the world a better place" (United Nations, 2021). This goal aims to strengthen global partnerships for sustainable development. Task 17.6 of SDG 17 indicates "Knowledge Sharing and Cooperation for access to science, technology and innovation". It encourages international cooperation in different areas to share knowledge through improved coordination among Institutions. The authors firmly believe that the Virtual Journey-COIL as well as other similar initiatives are a step in the right direction to contributing to both SDGs.

\section{ACKNOWLEDGEMENTS}

The authors wish to thank University of Makeni and CEU SAN PABLO University for its crucial support.

\section{REFERENCES}

Brown, T. (2008): "Design Thinking," Harvard Business Review, June, pp. 8492.

Burner, T. (2018): "Why is educational change so difficult and how can we make it more effective?" Forskning og Forandring 1(1):122. DOI: 10.23865/fof.v1.1081

College of Education and Human Development, University of Minnesota (2016): "The COIL Handbook" (December 15th 2020). https:// champ.d.umn.edu/sites/champ.d.umn.edu/files/umn_cehd_coil_ workbook.pdf

Cutler, N.E. y Danowski, J.A., (1980): Process gratification in aging cohorts. Journalism Quarterly 57, 269-276. https://doi. org/10.1177/107769908005700210

Deardorff, D. K. (2016): "Identification and Assessment of Intercultural Competence as a Stu-dent Outcome of Internationalization." Journal of Studies in International Education, 10(3), 241-266

De Wit (2013): "COIL - Virtual mobility without commercialization" (February 28th 2021). https://www.universityworldnews.com/post. php?story=20130528175741647

Frank, E. y Aznar, G. (2020): "Smart City = Smart Citizen = Smart Economy?: An Economic Perspective of Smart Cities". https://doi. org/10.1177/107769908005700210

Herrero de Egaña Muñoz-Cobo, B. (2019): "Innovación social, Innovación Smart: nuevas respuestas frente a los desafíos de la humanidad". Revista: 
European Public \& Social Innovation Review (EPSIR). Sinnergiak Social Innovation, 4, (1) 27-52

Herrero de Egaña Muñoz-Cobo, B. (2018): "La innovación social en España: ejes vertebradores desde la Teoría Fundamentada" DOI:10.13140/RG.2.2.29795.91680, en https://www.researchgate. net/publication/339799564_La_Innovacion_Social_en_Espana_Ejes_ vertebradores_desde_la_Teoria_Fundamentada

Hoag, A. y T. F. Baldwin (2000): "Using case method and experts in interuniversity electronic learning teams". Educational Technology and Society 3(3), 337-348

Katz, E., Blumler, J.G. y Gurevitch, M.(1973): "Uses and Gratifications Research". The Public Opinion Quarterly 37, 509-523

Lakovleva, T., Kolvereid, L. y Stephan, U. (2011), “Entrepreneurial intentions in developing and developed countries", Education + Training, Vol. 53 No. 5, pp. 353-370. https://doi.org/10.1108/00400911111147686

Marciniak, R. (2017): "Propuesta metodológica para el diseño del proyecto de curso virtual: aplicación piloto". Apert. (Guadalaj., Jal.). 2017, 9, (2), 74-95. ISSN 2007-1094.

Martínez Usarralde, M.J. (2014). "Otras metodologías son posibles... y necesarias. Cuando la Cooperación al Desarrollo encontró al ApS (Aprendizaje Servicio)". Universidad y Cooperación al Desarrollo. Contribuciones de las universidades al Desarrollo Humano, 135-154, Valencia: Universidad Politécnica de Valencia.

MIT, "Professional certificate in digital transformation" (February 15th 2021). https://professionalprograms.mit.edu/professional-certificate-in-digitaltransformation/

Mitch H. and Milton B. (1998), "Developmental Model of Intercultural Sensitivity", Intercultural Development Inventory Manual, (Intercultural Communication Institute), 12-16.

OECD Education Working Papers (2020) No. 232. (February 25th 2021). http://www.oecd.org/coronavirus/policy-responses/the-impact-ofcovid-19-on-student-equity-and-inclusion-supporting-vulnerablestudents-during-school-closures-and-school-re-openings-d593b5c8/

Osterwalder A. y Pigneur Y. (2010): "Business model generation: A handbook for visionaries, game changers, and challengers". John Wiley \& Sons, Hoboken, New Jersey.

Phills J.A., Deiglmeier K. y Miller D.T., (2008):"Rediscovering social innovation", Stanf. Soc. Innov., (6), 34-43

Pol E., Ville S.(2009):" Social innovation: buzz word or enduring term?" J. Socio-Econ. 38, 878-885.

Raluca D.; Pellini,A.; Jordan, K. y Phillips, T. (2020): "Policy brief - Education during the COVID-19 crisis, Opportunities and constraints of using EdTech 
in low-income countries". Part of EdTech and coronavirus (COVID-19) series (January 5th 2021). http:www. edtechhub.org/coronavirus

Sluijsmans, D. M. A., S. Brand-Gruwel, J. Van Merriënboer, y T.R. Bastiaens (2003): "The Training of Peer Assessment Skills to Promote the Development of Reflection Skills in Teacher Education". Studies in Educational Evaluation 29(1): 23-42

Swan, K., P. Shea, E. Fredericksen, A Pickett, W. Pelz, G. Maher, G. (2000) "Building knowledge building communities: Consistency, contact and communication in the virtual classroom". Journal of Educational Computing Research 23(4): 389-413

SUNY COIL Centre (December 15th 2021). http://www.ufic.ufl.edu/uap/ forms/coil_guide.pdf

The Global Economy in Sierra Leone. (January 28th 2021). https://www. theglobaleconomy.com/Sierra-Leone/Mobile_phone_subscribers/

Wahab, A(2020): "Online and Remote Learning in Higher Education Institutes: A Necessity in Light of COVID-19 Pandemic"; Canadian Center of Science and Education, Higher Education Studies; 10, (3), 16-25; doi:10.5539/ hes.v10n3p16; URL: https://doi.org/10.5539/hes.v10n3p16

Willms, J. D.; Corbett, B. A. (2003): "Tech and teens: access and use. Canadian SocialTrends", 15-20.

Wittels A. y Maybanks N. (2016) Communication in Sierra Leone:"An analysis of media and mobile audiences.(January 28th 2021). https:// assets.publishing.service.gov.uk/media/57a0896040f0b6497400004a/ mobile-media-landscape-sierra-leone-report.pdf

United Nations (2021): "The Global Goals for Sustainable Development", (15th December 2021). https://www.globalgoals.org

Worldbank (2018a): "World Development Indicators database, Country profile Sierra Leone" (February 15th 2021) from https://databank. worldbank.org/views/reports

Worldbank (2018b): "World Development Indicators database" Country profile Spain retrieved from https://databank.worldbank.org 